\title{
Synthesis and Characterization of Organic Bio-Absorbents Coming from Sugarcane Bagasse
}

\author{
Israel Hernández Romeroㅁ, Juan Rodrigo Laguna Camacho², \\ Raúl Enrique Contreras Bermúdez ${ }^{1}$ Francisca Sandoval Reyes', Erika Gaona Santiago', \\ Celia María Calderón Ramón ${ }^{2}$, Lizeth Ríos Velasco'ㄹ, Jesús Enrique Escalante Martínez ${ }^{2 *}$ \\ ${ }^{1}$ Facultad de Ciencias Químicas de la Universidad Veracruzana, Tuxpan, México \\ ${ }^{2}$ Facultad de Ingeniería Mecánica de la Universidad Veracruzana, Tuxpan, México \\ Email: "jeescalante@uv.mx
}

Received 1 May 2016; accepted 15 July 2016; published 18 July 2016

Copyright (C) 2016 by authors and Scientific Research Publishing Inc.

This work is licensed under the Creative Commons Attribution International License (CC BY). http://creativecommons.org/licenses/by/4.0/

\section{(c) (i) Open Access}

\begin{abstract}
In this work, a modification of the sugarcane bagasse is performed, in order to obtain organic catalysts. The bagasse analysis is performed using X-ray diffraction (XRD) and Fourier Transformer Infrared Spectroscopy (FTIR), which indicated that characteristic peaks determined its chemical compounds. In addition, Scanning Electron Microscopy (SEM) is used to know the morphology. Finally, a discoloration test is conducted on an azo compound (methylene blue) in an aqueous medium, obtaining an efficiency of $98.6 \%$.
\end{abstract}

\section{Keywords}

Organic Bio-Absorbents, Natural and Modified Sugarcane Bagasse, Methylene Blue, Sugarcane Bagasse Characterization

\section{Introduction}

The fibrous agricultural residues depict $50 \%$ of the total production of organic matter of vegetable farming. In Mexico, an abundant crop residue, is the cultivation of grain corn (stover); it had estimated that the corn surface planted in the last 6 years, was around 8.4 million hectares per agricultural year (average area). The corn production was between 14 and 18 million tons per crop year since 2007.

${ }^{*}$ Corresponding author. 
On the other hand, the waste generated by the sugar industry in the manufacturing process, is the sugarcane bagasse. It is estimated that for every ton of sugarcane generates 150 or $160 \mathrm{~kg}$ of dry sugarcane bagasse.

The sugarcane (Saccharum officinarum L.) is a tropical grass, a giant grass related to sorghum and maize. It comes from the Far East, where it arrived to Spain in the ninth century. In Mexico appeared after the Conquest, settling the first sugar industries in the warm parts of the country, as part of the colonization. It supplies $70 \%$ of global demand for sugar followed by beet. The sugar obtains from fresh and sweet cane juice, the leaves and stems use as fodder for livestock. There are different types of sugar, from piloncillo or panela (powdered brown sugar) to refined sugar, which is used as a staple food of human or as raw material for industry. It transforms into ethyl alcohol, lactic acid, dextrose and glycerin [1]-[3]. It is one of economic main sources in 15 states and 227 towns of the Mexican Republic; nevertheless sugarcane plants and processes are presented in 667 communities [4]. The top producing states are Veracruz, followed by Jalisco, where reached 6 tons every year and Oaxaca [5]. Currently, and due to environmental issues in Mexico, the sugarcane is a reference as a source of biomass for renewable energy. More than $70 \%$ of the production of waste from the sugar industry is destined for the production of bioethanol. The use of biomass for energy in Mexico represents 8\% of the primary energy demand and focuses on the use of residential wood and small industries and the use of bagasse in sugar mills. However, bioenergy has a much wider potential and could become one of the pillars of sustainable development in Mexico [6].

Water pollution is a major environmental problem faced by modern society [7] that leads to ecological disequilibrium and health hazards [8]. Many efforts have made recently to find cheaper pollution control methods and materials [9]-[11]. The new material world trends point to the importance of using industrial and agricultural residues as production starting materials. Reusing and recycling these residues can minimize the environmental problems associated with their build-up and reduce the use of noble starting materials. This trend has contributed to the reconsideration of the use of traditional biomaterials such as natural lignocellulosic fibers to substitute synthetic polymers, for example, since in many cases they have a better performance [12]. Accordingly, it has increased the importance of recycling. Sugarcane bagasse has around 50\% cellulose, $27 \%$ polyoses, and $23 \%$ lignin [13]. These three biological polymers have many hydroxyl and/or phenolic functions that can be chemically reacted to produce materials with new properties [14] [15]. The remaining bagasse continues to be a menace to the environment and a suitable utilization of this residue is an important target to be pursued [16].

Despite the many studies of the chemical modification of cellulose published around the world in this area [17] [18], only a few have investigated the modification of bagasse sugar [19] [20].

Due to this fact, in the present study, the sugarcane bagasse examined using three different characterization techniques, Scanning Electron Microscopy (SEM), Fourier Transformer Infrared Spectroscopy (FTIR) and X-ray diffraction (XRD), to be used as a bio-absorbent for the azo compound discoloration.

\section{Materials and Methods}

\subsection{Materials}

The organic material used in this research, sugarcane bagasse, found in the North part of the state of Veracruz, where the crop is naturally exploited by the conditions that owns the land. The sugarcane bagasse obtained in the community of Rancho Alegre, Mecatlán Town, Veracruz. On the other hand, the $\mathrm{H}_{3} \mathrm{PO}_{4}$ acid (Aldrich brand) was provided by the Faculty of Chemistry of the Universidad Veracruzana, Campus Poza Rica-Tuxpan.

\subsection{Bio-Absorbents Preparation and Characterization}

It required 80 - 100 pieces approximately $60 \mathrm{~cm}$ long of sugarcane bagasse to obtain only $250 \mathrm{~g}$ of solid material corresponding to each of the samples; $10 \mathrm{mg}$ used to conduct the characterization procedure. Subsequently, the chemical modification of the organic material (sugarcane bagasse) carried out using $0.80 \%$ of $\mathrm{H}_{3} \mathrm{PO}_{4}$ acid for impregnation. Finally, the characterization tests of both natural and modified materials, performed. In relation to the characterization, micrographs of the morphology of the sugarcane bagasse, natural and modified, obtained using a Scanning Electron Microscope (SEM) Quanta 3D FEG (FEI). Then, Fourier Transformer Infrared Spectroscopy (FTIR) used to identify the elucidation of functional groups present in the molecular structures of sugarcane bagasse in both, natural and modified states, an $\mathrm{IR}^{2}$ module of infrared spectroscopy used by Illiminat Fourier Transform IR from Horiba JobinYvon coupled to a micro-Raman confocal spectrometer Labram HR800 from Horiba Jobin Yvon. Finally, the X-ray diffraction performed on a Rigaku Miniflex 600 equipment. 


\subsection{Discoloration of Azo Compound}

The discoloration of the azo compound (methylene blue) performed in aqueous medium in a batch reactor to verify the efficiency of bioabsorption of the prepared material.

\section{Results and Discussion}

\subsection{Morphology of Sugarcane Bagasse}

Figures 1-3 show the natural material micrographs where it is possible to observe the disintegration of the sugarcane bagasse after the drying process. The bagasse tissue has a cellular structure composed of medulla, mainly formed of parenchymal cells of thin, elastic walls and numerous perforations. Besides being associated with fibrovascular bundles, which are thin, thin-walled with blunt ends, forks and their surfaces occasionally have small pores [21]. On the other hand, the bark fibers lignified, with higher length, diameter and thicker walls and pores present in the entire surface [22] [23]. It observes in the SEM micrographs (Figure 1) where it is possible to appreciate regular sharp extreme fibers, but in this particular case with lengths of 10 - 40 microns.

The fibers of (Figure 2 and Figure 3) also present sharp edges and the significant length of $100-400$ microns represents the own cane size [24]. As the fibers coat by soft tissue, there is the presence of sclerotic cells and

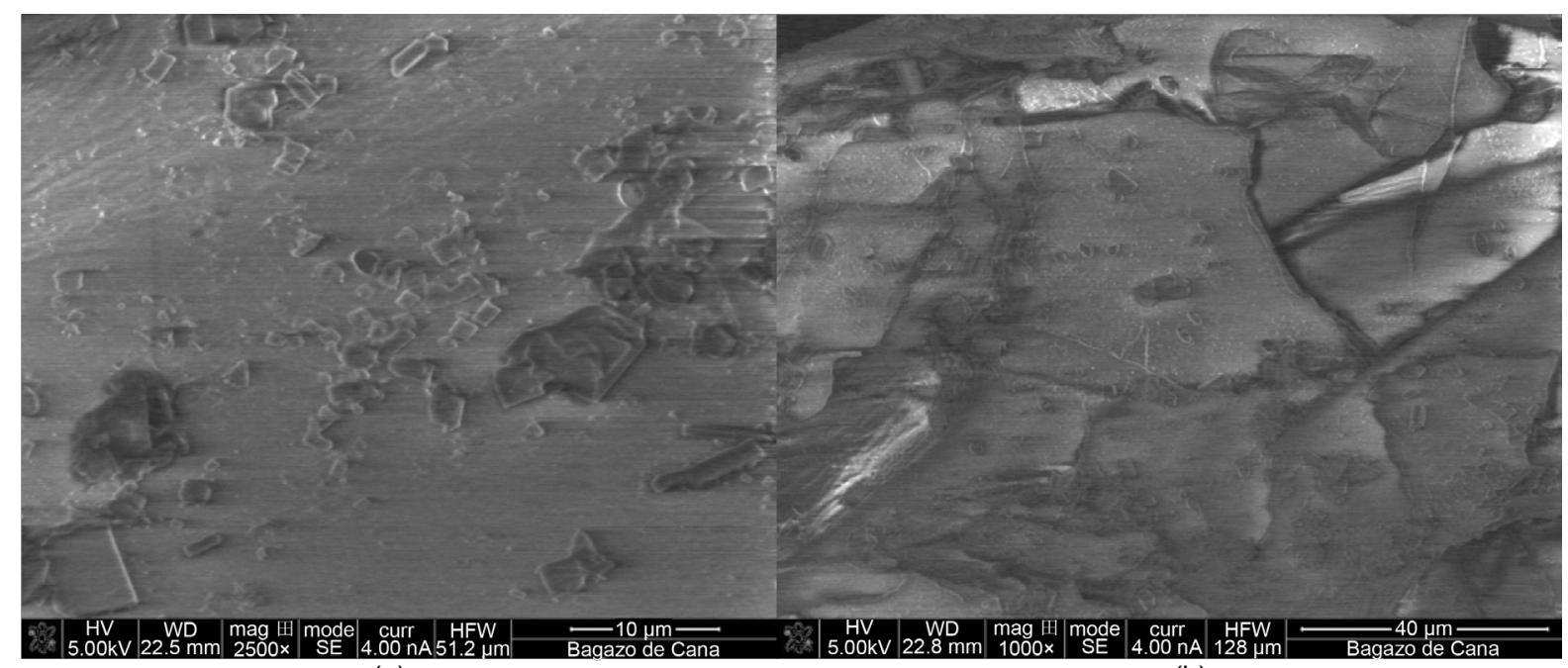

(a)

(b)

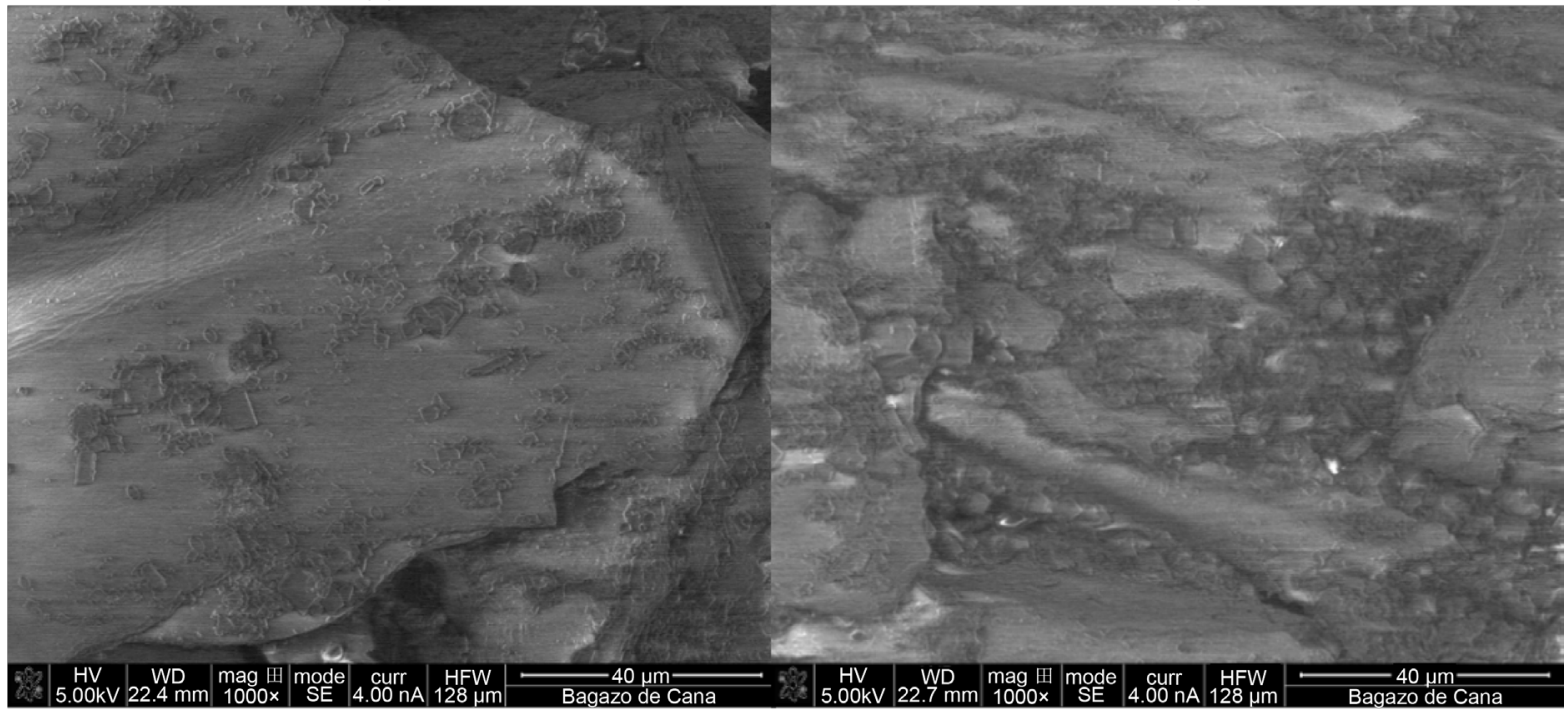

(c)

(d)

Figure 1. (a)-(d) SEM micrographs of the natural sugarcane bagasse $(10-40 \mu \mathrm{m})$. 


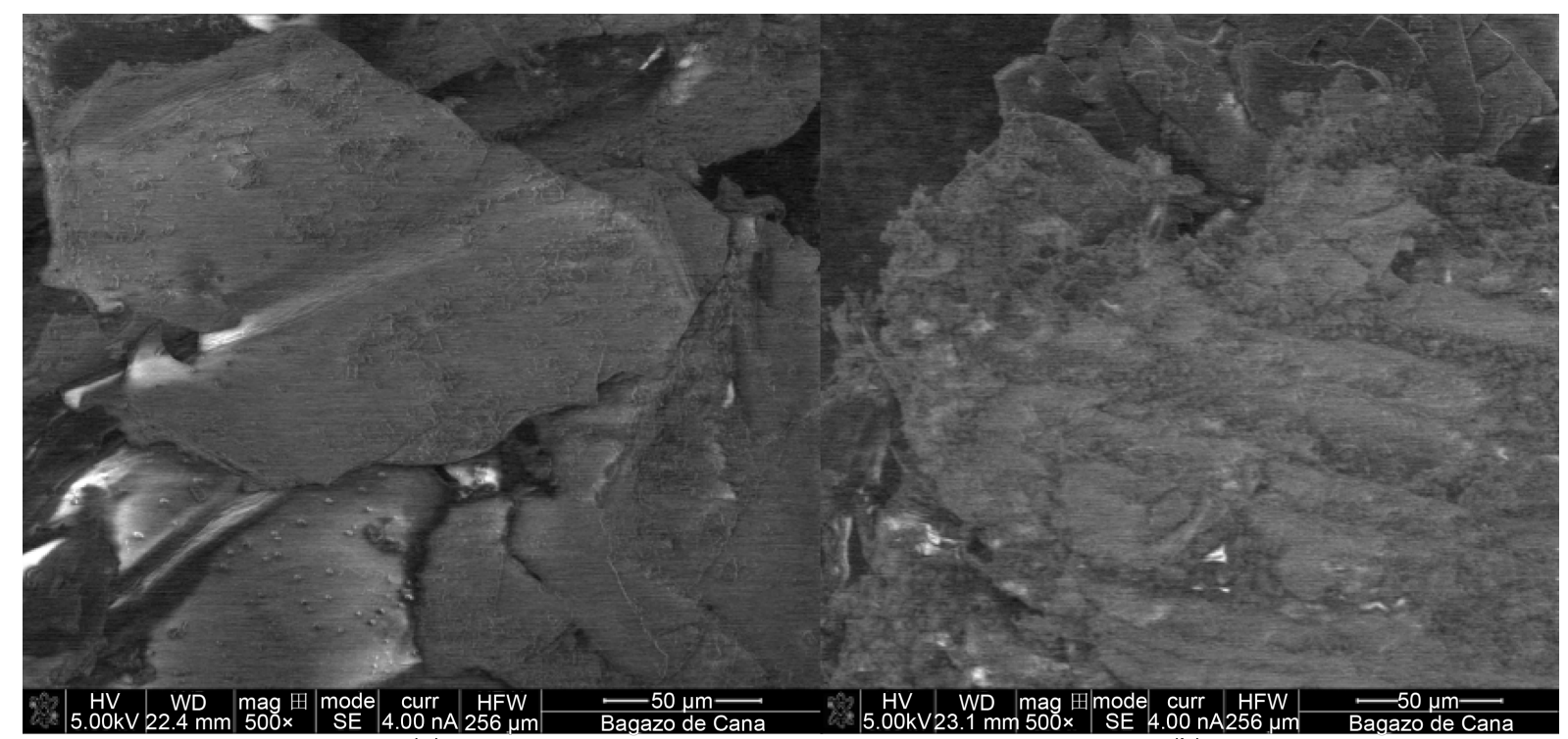

(a)

(b)

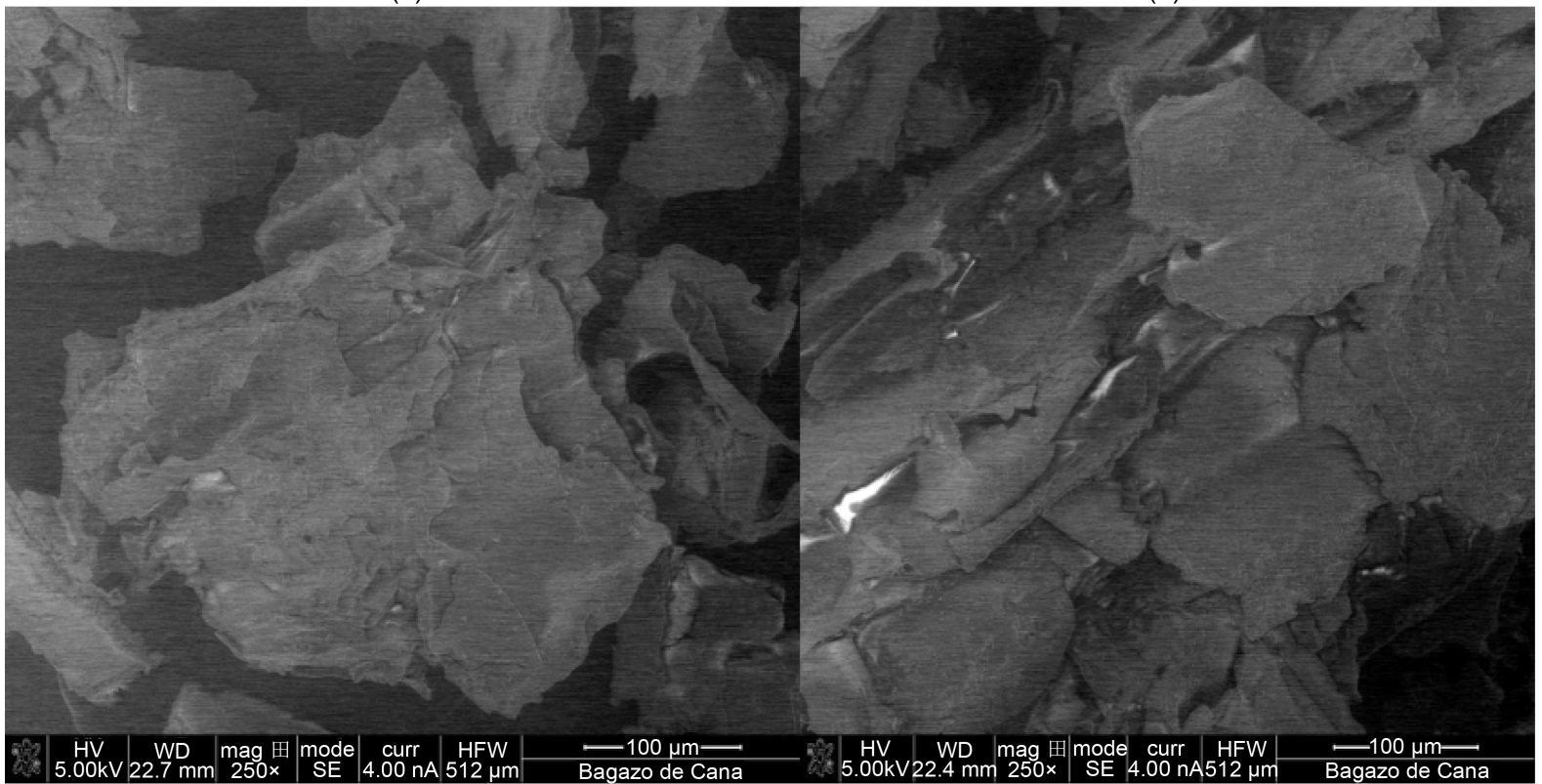

(c)

(d)

Figure 2. (a)-(d) SEM micrographs of the natural sugarcane bagasse $(50-100 \mu \mathrm{m})$.

parenchymal cells with rounded shapes that appear with no perforated ends, thin wall and crossed by small canaliculus. In addition, vessel elements (Figure 4) present like cylindrical sieve tubes and other ringed. The cylindrical vessels are of variable size, simple and oval tips. Ringed vessels are of smaller size and more isolated.

\subsection{Fourier Transformer Infrared Spectroscopy (FTIR)}

The infrared spectra of each sample obtained using an ATR objective. In this particular case, a comparison conducted between unmodified and modified samples in relative scale and an absorbance presentation. Figure 4(a) shows bands in the spectrum at 866.7, 907.6, 987.6, 1047.1, 1236.8, 1342.8, 1424.6, 2940.4, 3310.5, 3373.5 and $3554.2 \mathrm{~cm}^{-1}$. These results are coherent to study of Mothé-Miranda [25]. In relation to spectrum in (Figure 4(b)), it shows that the bands exhibit a shift in their position but remain within the corresponding spectral range, making infer symmetry loss of sucrose to a "semi-amorphous state”.

This information corroborated by the analysis of Salgado-Delgado [26], where it was possible to observe that 


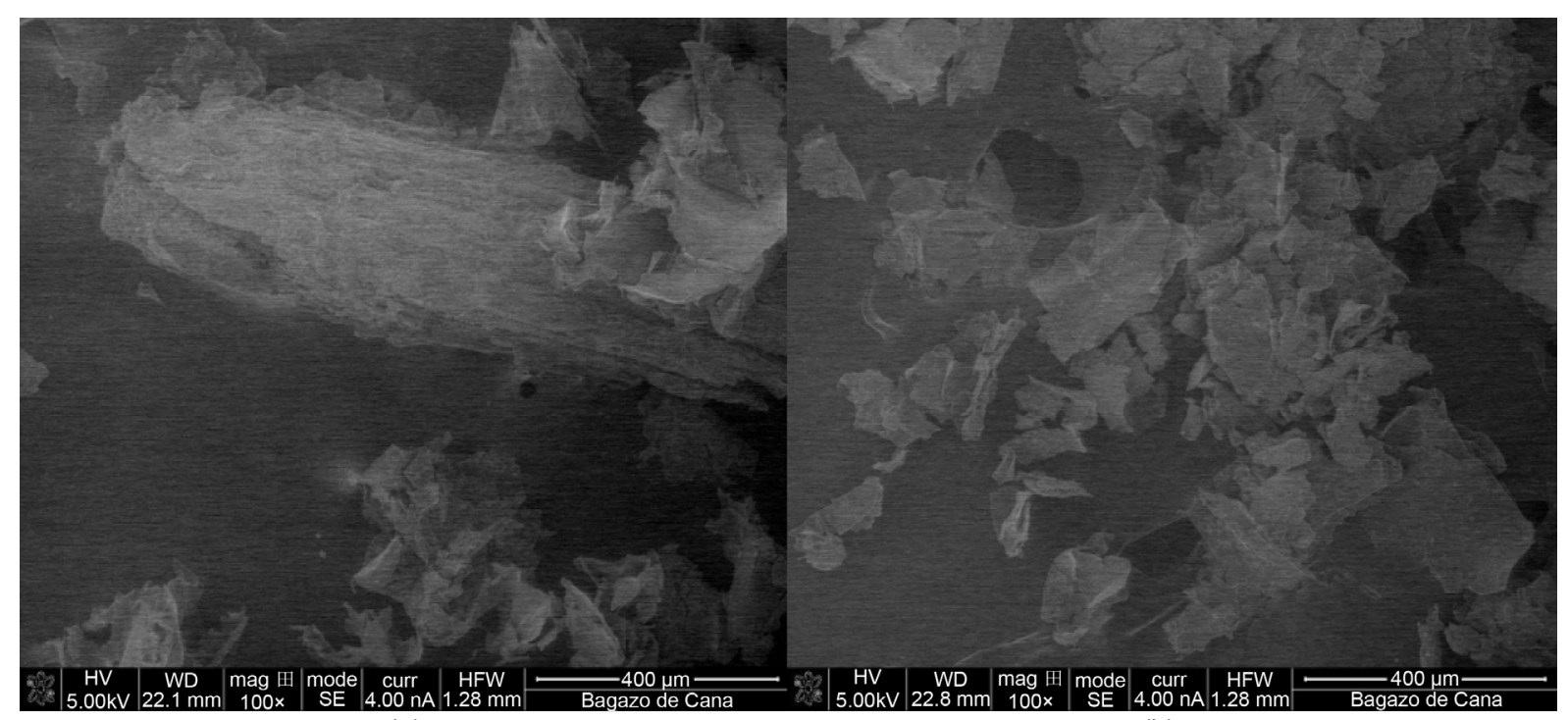

(a)

(b)

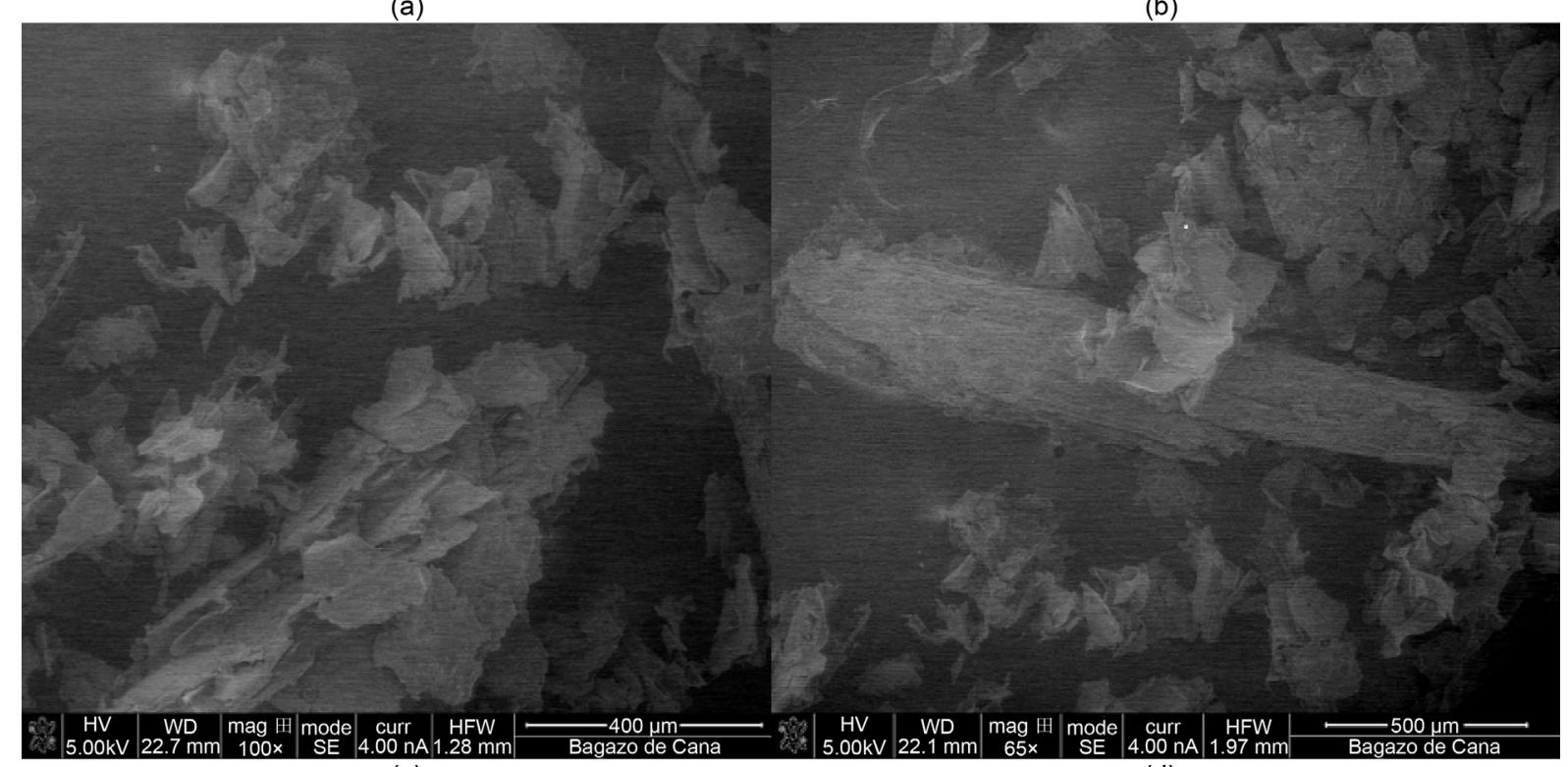

(c)

(d)

Figure 3. (a)-(d) SEM micrographs of the natural sugarcane bagasse (400 - $500 \mu \mathrm{m})$.

the treatment modified the surface of the sugarcane bagasse cellulose. It was because the treatment led to vanish the signal $1700-1756 \mathrm{~cm}^{-1}$ that corresponded to the stretching of $\mathrm{C}=\mathrm{O}$ [27], present in the lignin, and decreased the stretching signal of $\mathrm{C}=\mathrm{C}\left(1600 \mathrm{~cm}^{-1}\right)$ corresponding to the aromatic ring present in the lignin. All bands influenced by the transformation related to the change of intra and intermolecular bonds [28]. It noted that the large removal of lignin could attribute to the disappearance of the bands at 1604, 1514 and $1252 \mathrm{~cm}^{-1}$ [29]. The absorbance of the band at $1377 \mathrm{~cm}^{-1}$, corresponding to the deformation by vibration of $\mathrm{C}$ - $\mathrm{H}$, decreased due to the high lignin removal [30].

\subsection{X-Ray Diffraction}

Figure 5 and Figure 6 show the X-ray diffractograms of natural and modified sugarcane bagasse, respectively. The first graph (Figure 5) shows characteristic peaks of a phenomenon of forced dispersal by electrons scattering the X-rays in all directions. However, (Figure 6) shows a uniform diffractogram with only one characteristic peak, which indicate that there is a widening of the material due to the possible presence of small crystals. In general, with a smaller crystal size there will be much wider diffraction peaks. 


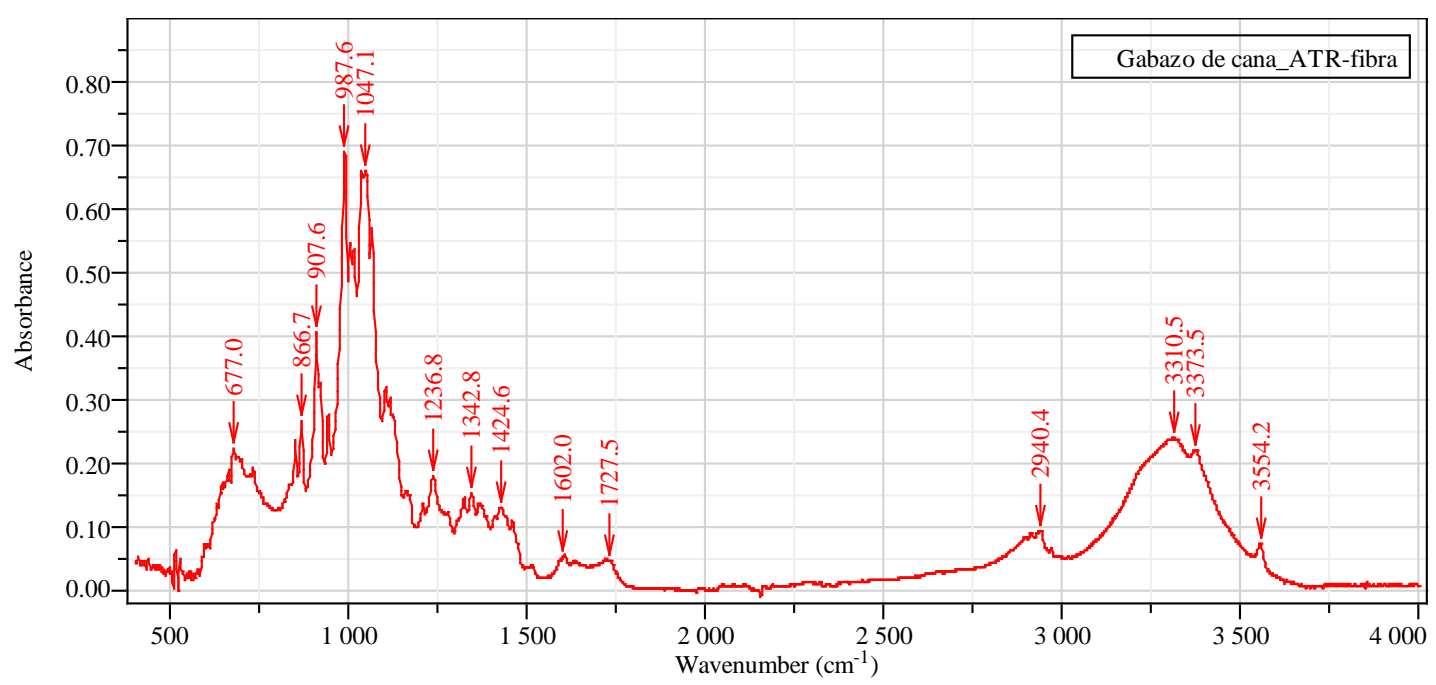

(a)

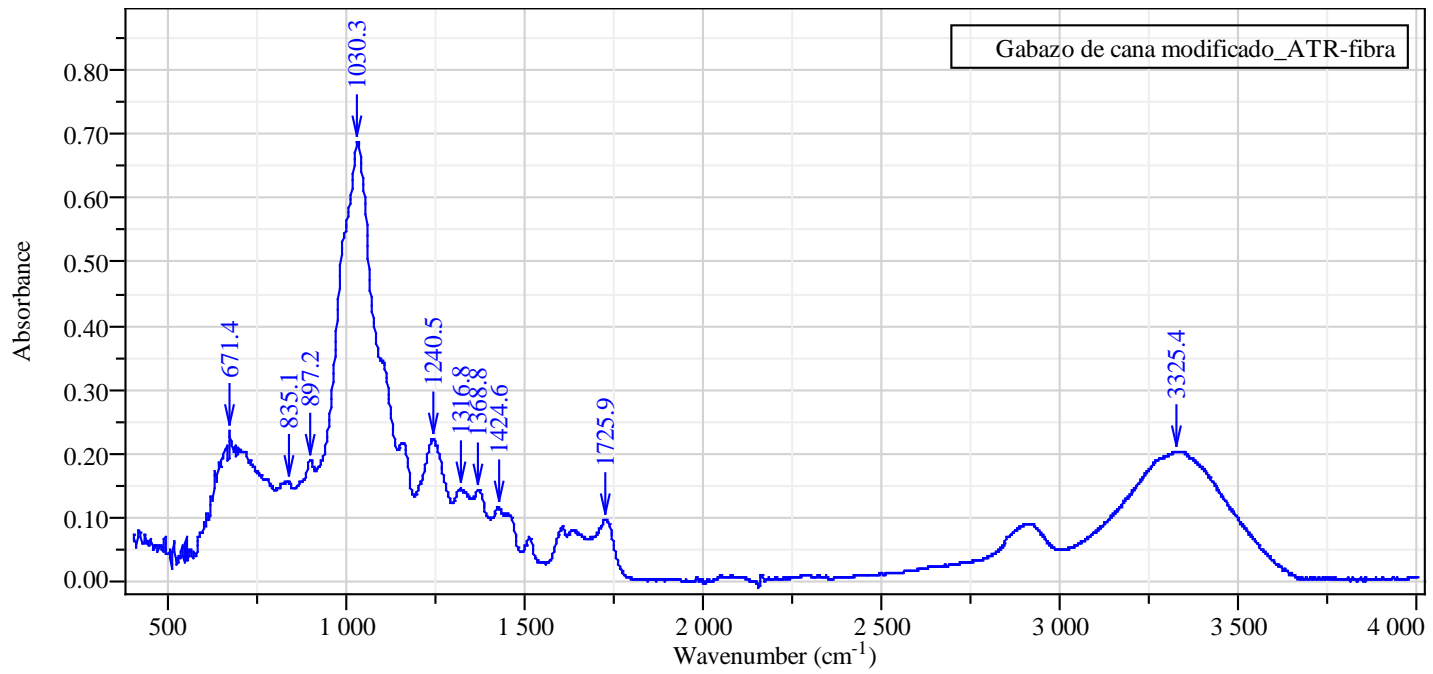

(b)

Figure 4. (a) FTIR spectrum of natural sugarcane bagasse fibers and (b) Spectrum of modified sugarcane bagasse fibers.

The sugarcane bagasse pretreatment has shown typical reflections of polymorphic form attributed to the native cellulose [27]. After modification, a significant mass loss of amorphous cellulose and lignin, observed (Figure 6).

\subsection{Discoloration of Azo Compound (Methylene Blue)}

In accordance to the sugarcane bagasse results obtained as bio-absorbent, it proved with an azo compound (methylene blue) in aqueous medium, with an initial concentration of $10 \mathrm{ppm}$. The best results obtained with $0.80 \%$ of phosphoric acid (98.65\% adsorption). Figure 7 shows the sugarcane bagasse with the same acid, showing that its efficiency is very good and similar to those results reached in other research work [31], using the same concentration of dye in $30 \mathrm{~min}$ time with the biomass Morinda citrifolia (L.).

\section{Conclusions}

It successfully carried out the chemical modification of sugarcane bagasse through the phosphoric acid.

Based on the X-Ray Diffraction (XRD) patterns, these showed the presence of characteristic peaks of sucrose, cellulose and lignin, which corresponded to amorphous materials, so that; there was a widening of the material due to the possible presence of small crystals. 


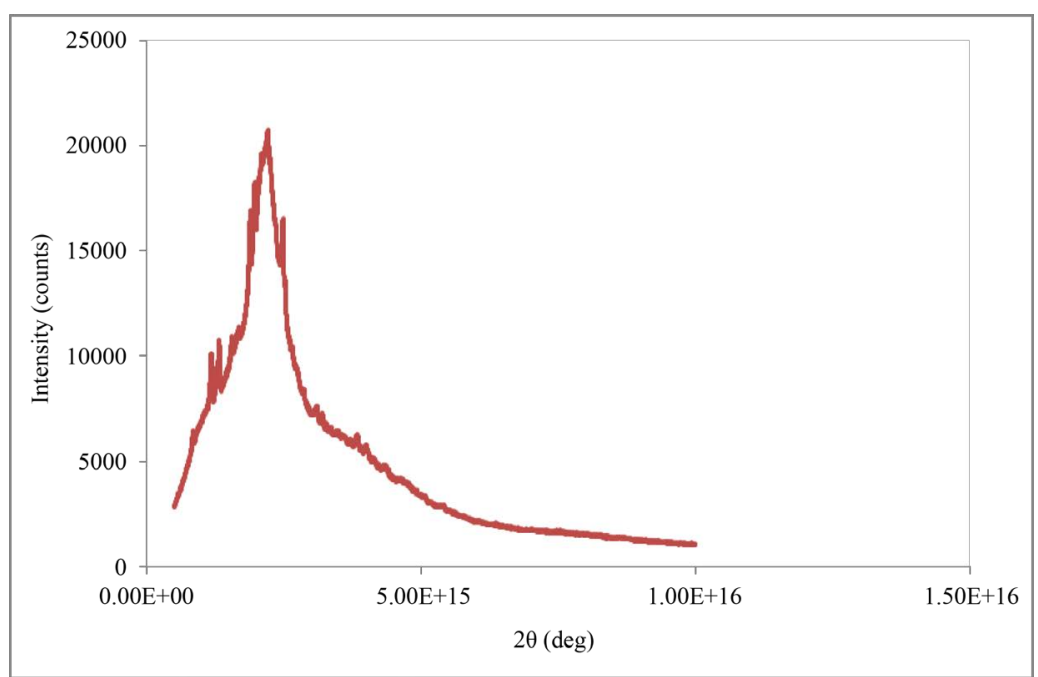

Figure 5. XRD diffractogram of natural sugarcane bagasse.

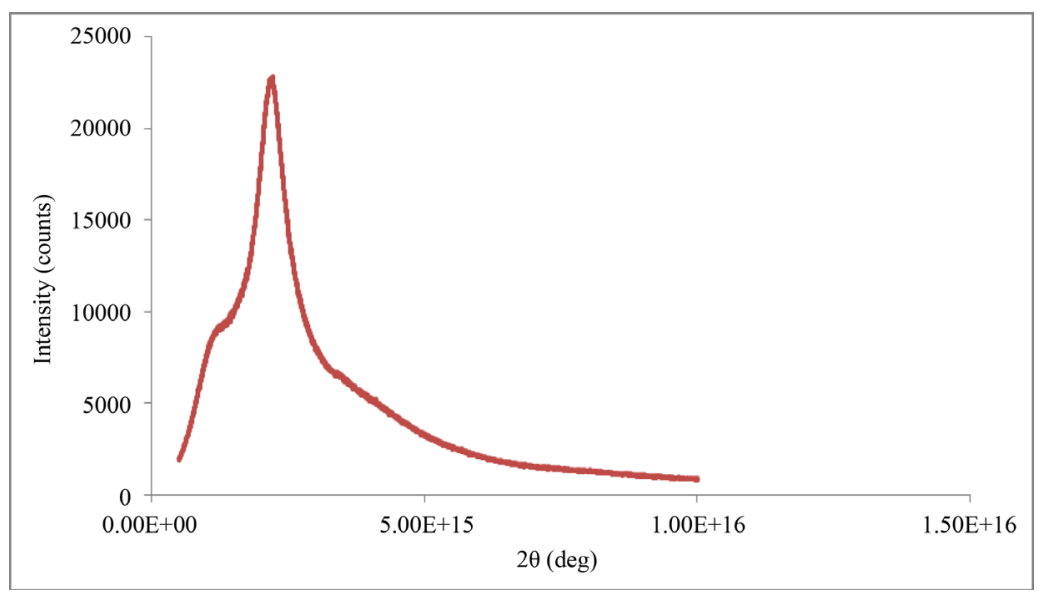

Figure 6. XRD diffractogram of modified sugarcane bagasse.

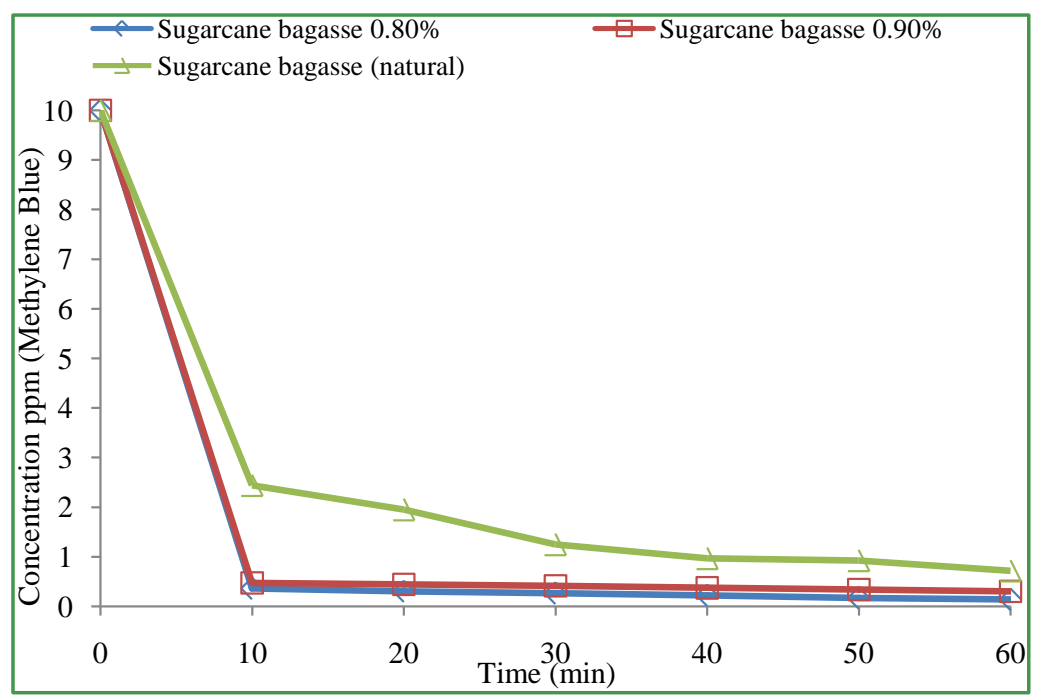

Figure 7. Concentration ppm versus time of the azo compound (methylene blue) with natural and modified sugarcane bagasse. 
These results were similar to that obtained in the Fourier Transformer Infrared Spectroscopy (FTIR). The spectra showed bands mainly related to sucrose, and little intervention of lignin in the case of bagasse; impregnation did not alter the natural sample, so it was possible to conclude that the acid used for impregnation was a convenient medium.

In respect to SEM images, the morphologies of the natural and modified samples were clearly identified. Fibers with sharp edges with the presence of sclerotic cells and parenchymal cells of rounded shapes with no perforated ends, thin walls and grooved, observed in the natural sugarcane bagasse. On the other hand, sieve vessels and completely disintegrated and clean fibers appreciated on the modified samples.

The discoloration of methylene blue in the modified bagasse with phosphoric acid, proved to be very efficient, obtaining an efficiency of $98.65 \%$ absorption.

\section{Acknowledgements}

The authors would like to thank experimental support CNMN-IPN (Center for Nanoscience and Micro and Nanotechnology) of the National Polytechnic Institute in carrying out the presented work.

\section{References}

[1] Rutiaga-Quiñones, J.G., Anzaldo-Hernández, J., Vargas-Radillo, J.J. and Sanjuán-Dueñas, R. (2002) Propiedades de resistencia de una pulpa kraft de pino mezclada con médula del bagazo de caña de azúcar. Madera y Bosques, 8, 17.

[2] Sidney, G.E. (1991) TAPPI Non-Wood Plant Fiber Pulping Progress. Rep. 19, Atlanta, 45-48.

[3] Matta, J.E. (1991) Papel periódico con bagazo y/o caña. II. Potencionalidad y manejo de las fibras. ATIPCA, 30, 56.

[4] Aguilar-Rivera, N. (2011) Efecto del almacenamiento de bagazo de caña en las propiedades físicas de celulosa grado papel. Ingeniería, Investigación y Tecnología, 12, 189.

[5] Sagarpa (2010) Situación actual del azúcar. Mexico, 1-9.

[6] Conafor (2007-2012) Programa nacional de dendroenergía forestal. Mexico, 1-12.

[7] Baird, C. (1995) Environmental Chemistry. W.H. Freeman and Company, New York.

[8] Kelter, P.B., Grundman, J., Hage, D.S., Carr, J.D. and Castro-Acuña, C.M. (1997) A Discussion of Water Pollution in the United States and Mexico; with High School Laboratory Activities for the Analysis of Lead, Atrazine, and Nitrate. Journal of Chemical Education, 74, 1413. http://dx.doi.org/10.1021/ed074p1413

[9] Panday, K.K., Prasad, G. and Singh, V.N. (1985) Copper(II) Removal from Aqueous Solutions by Fly Ash. Water Research, 19, 869-873. http://dx.doi.org/10.1016/0043-1354(85)90145-9

[10] Al-Haj Ali, A. and El-Bishtawi, R. (1997) Removal of Lead and Nickel Ions Using Zeolite Tuff. Journal of Chemical Technology and Biotechnology, 69, 27-34. http://dx.doi.org/10.1002/(SICI)1097-4660(199705)69:1<27::AID-JCTB682>3.0.CO;2-J

[11] Acemioglu, B. and Alma, M.H. (2001) Equilibrium Studies on Adsorption of Cu(II) from Aqueous Solution onto Cellulose. Journal of Colloid and Interface Science, 243, 81-84. http://dx.doi.org/10.1006/jcis.2001.7873

[12] Karnitz-Jr., O., Alves-Gurgel, L.V., Perin de Melo, J.C., Botaro, V.R., Sacramento Melo, T.M., Pereira de Freitas Gil, R. and Frédéric Gil, L. (2007) Adsorption of Heavy Metal Ion from Aqueous Single Metal Solution by Chemically Modified Sugarcane Bagasse. BioresourceTechnology, 98, 1291-1297. http://dx.doi.org/10.1016/j.biortech.2006.05.013

[13] Caraschi, J.C., Campana Filho, S.P. and Curvelo, A.A.S. (1996) Carboximetilação de polpas de bagaço de cana de açúcar e caracterização dos materiaisabsorventesobtidos. Polímeros. Ciencia y Tecnología, 3, 24.

[14] Xiao, B., Sun, X.F. and Sun, R.C. (2001) The Chemical Modification of Lignins with Succinic Anhydride in Aqueous Systems. Polymer Degradation and Stability, 71, 223-231. http://dx.doi.org/10.1016/S0141-3910(00)00133-6

[15] Navarro, R.R., Sumi, K., Fujii, N. and Matsumura, M. (1996) Mercury Removal from Wastewater Using Porous Cellulose Carrier Modified with Polyethyleneimine. Water Research, 30, 2488-2494. http://dx.doi.org/10.1016/0043-1354(96)00143-1

[16] Sun, J.X., Sun, X.F., Zhao, H. and Sun, R.C. (2004) Isolation and Characterization of Cellulose from Sugarcane Bagasse. Polymer Degradation and Stability, 84, 331-339. http://dx.doi.org/10.1016/j.polymdegradstab.2004.02.008

[17] Gellerstedt, F. and Gatenholm, P. (1999) Surface Properties of Lignocellulosic Fibers Bearing Carboxylic Groups. Cellulose, 6, 103-121. http://dx.doi.org/10.1023/A:1009239225050

[18] Gurnani, V., Singh, A.K. and Venkataramani, B. (2003) 2,3-Dihydroxypyridine-Loaded Cellulose: A New Macromolecular Chelator for Metal Enrichment Prior to Their Determination by Atomic Absorption Spectrometry. Analytical 
and Bioanalytical Chemistry, 377, 1079-1086. http://dx.doi.org/10.1007/s00216-003-2121-9

[19] Anoop-Krishnan, K. and Anirudhan, T.S. (2002) Removal of Mercury(II) from Aqueous Solutions and Chlor-Alkali Industry Effluent by Steam Activated and Sulphurised Activated Carbons Prepared from Bagasse Pith: Kinetics and Equilibrium Studies. Journal of Hazardous Materials, 92, 161-183. http://dx.doi.org/10.1016/S0304-3894(02)00014-6

[20] Orlando, U.S., Baes, A.U., Nishijima, W. and Okada, M. (2002) Preparation of Chelating Agents from Sugarcane Bagasse by Microwave Radiation as an Alternative ecologically Benign Procedure. Green Chemistry, 4, 555-557. http://dx.doi.org/10.1039/b203440a

[21] Prado-Martínez, M., Anzaldo-Hernández, J., Becerra-Aguilar, B., Palacios-Juárez, H., Vargas-Radillo, J.J. and Rentería-Urquizam, M. (2012) Caracterización de hojas de mazorca de maíz y de bagazo de caña para la elaboración de una pulpa celulósica mixta. Madera y Bosques, 18, 37-51.

[22] Adamopoulos, S. (2006) Identification of Fibre Components in Packaging Grade Papers. IAWA Journal, 27, $153-172$. http://dx.doi.org/10.1163/22941932-90000145

[23] Triana, O. (1990) Atlas del bagazo de la caña de azúcar (Editorial Geplacea, Cuba 9). 39-43.

[24] Alves-Rezende, C., Aparecida de Lima, M., Maziero, P., Ribeiro de Azevedo, E., Garcia, W. and Polikarpov, I. (2011) Chemical and Morphological Characterization of Sugarcane Bagasse Submitted to a Delignification Process for Enhanced Enzymatic Digestibility. Biotechnology for Biofuels, 4, 54. http://dx.doi.org/10.1186/1754-6834-4-54

[25] Mothé, C.G. and de Miranda, I.C. (2009) Characterization of Sugarcane and Coconut Fibers by Thermal Analysis and FTIR. Journal of Thermal Analysis and Calorimetry, 97, 661-665.

[26] Salgado-Delgado, R., Coria-Cortés, L., García-Hernández, E., Vargas-Galarza, Z., Rubio-Rosas, E. and Crispín-Espino, I. (2010) Elaboración de materiales reforzados con carácter biodegradable a partir de polietileno de baja densidad y bagazo de caña modificado. Revista Iberoamericana de Polímeros, 11, 520-531.

[27] Alves Gurgel, L.V., Pereira de Freitas, R. and Frédéric Gil, L. (2008) Adsorption of Cu(II), Cd(II), and Pb(II) from Aqueous Single Metal Solutions by Sugarcane Bagasse and Mercerized Sugarcane Bagasse Chemically Modified with Succinic Anhydride. Carbohydrate Polymers, 74, 922-929. http://dx.doi.org/10.1016/j.carbpol.2008.05.023

[28] Yuh-Shan, H., Wen-Ta, C. and Chung-Chi, W. (2005) Regression Analysis for the Sorption Isotherms of Basic Dyes on Sugarcane Dust. Bioresource Technology, 96, 1285-1291. http://dx.doi.org/10.1016/j.biortech.2004.10.021

[29] López, R., Poblano, V.M., Licea-Claveríe, A., Avalos, M., Alvarez-Castillo, A. and Castaño, V.M. (2000) Alkaline Surface Modification of Sugar Cane Bagasse. Advanced Composite Materials, 9, 99-108. http://dx.doi.org/10.1163/15685510051029219

[30] Schwanninger, M., Rodrigues, J.C., Pereira, H. and Hinterstoisser, B. (2004) Effects of Short-Time Vibratory Ball Milling on the Shape of FT-IR Spectra of Wood and Cellulose. Vibrational Spectroscopy, 36, 23-40. http://dx.doi.org/10.1016/j.vibspec.2004.02.003

[31] Campos-Medina, E., Gómez-Hinojos, A.M. and Velázquez-Rodríguez, A. (2011) Estudio de la remoción del colorante azul de metileno empleando la biomasa de la Morinda citrocifolia L. Quivera, 13, 52-62.

\section{Submit or recommend next manuscript to SCIRP and we will provide best service for you:}

Accepting pre-submission inquiries through Email, Facebook, Linkedin, Twitter, etc

A wide selection of journals (inclusive of 9 subjects, more than 200 journals)

Providing a 24-hour high-quality service

User-friendly online submission system

Fair and swift peer-review system

Efficient typesetting and proofreading procedure

Display of the result of downloads and visits, as well as the number of cited articles

Maximum dissemination of your research work

Submit your manuscript at: http://papersubmission.scirp.org/ 